\title{
Nutritional Value and Microbiological Quality of Weaning Porridges in the Rural Area of Zokolilié, Ivory Coast
}

\author{
Gnagne Sylvain, Gbogouri Grodji Albarin, Agbo A. Edith, Kouakou Brou \\ Department of Food Sciences and Technology, Laboratory of Nutrition and Food Safety, Nangui Abrogoua University, Abidjan, Ivory Coast \\ Email address: \\ gnagne.sylvain@yahoo.fr (G. Sylvain) \\ To cite this article: \\ Gnagne Sylvain, Gbogouri Grodji Albarin, Agbo A. Edith, Kouakou Brou. Nutritional Value and Microbiological Quality of Weaning \\ Porridges in the Rural Area of Zokolilié, Ivory Coast. International Journal of Nutrition and Food Sciences. Vol. 6, No. 2, 2017, pp. 83-87. \\ doi: $10.11648 /$ j.ijnfs.20170602.14
}

Received: January 26, 2017; Accepted: February 10, 2017; Published: February 27, 2017

\begin{abstract}
The aim of this study is to evaluate the nutritional and microbiological quality of ten weaning porridges in the rural area of Zokolilié in south-west of Ivory Coast. Ten weaning porridges often consumed by children in Zokolilia were selected for biochemical and microbiological analyzes. The ten porridges are rich in carbohydrates with rates ranging from $70 \mathrm{~g} / 100 \mathrm{~g}$ of dry mater to $92 \mathrm{~g} / 100 \mathrm{~g}$ of dry mater. The slurries are poor in fiber and protein. The BMaArSo slurry has a very high [phytate] / [iron] ratio of 11. Microorganisms (B.Mi 0.03 $\pm 0.04 \times 104$ CFU / G B.Bis $0.004 \pm 0.0001104$ CFU / g BRiSor $0.5 \pm 0.04104 \mathrm{CFU} / \mathrm{g})$.
\end{abstract}

Keywords: Weaning Porridge, Microbiological Quality, Nutritional Quality, Ivory Coast

\section{Introduction}

According to the Food and Agriculture Organization of the United Nations (FAO), more than 25,000 people die every day from undernourishment and over 800 million are chronically undernourished. Most of these people live in developing countries. Moreover, in a 2014 report, the World Health Organization (WHO) estimates that more than one-third of children under five years of age in developing countries were malnourished [1]. In developing countries, protein-energy malnutrition and micronutrient deficiency are real public health problems [2]. Studies conducted by WHO in 2001 showed that children from 0 to 5 years are particularly vulnerable to these nutritional disorders because any deficiency at this age can lead to irreversible consequences. In addition, it was established that a child who does not get enough nutrients in his daily diet is exposed to various forms of malnutrition such as protein-energy malnutrition (PEM), nutritional anemia and xerophthalmia. Besides these three forms of malnutrition, it should be added calcium deficiency which has a significant impact on the growth of the child. It is unfortunately not uncommon that a child bears both and to varying degrees traces of these different forms of malnutrition [3]. Malnutrition occurs mainly in children between 0 and 2 years of age. During the first two years of life, the prevalence of malnutrition increases with the age of the child. Children under 6 months are the least affected (8.2\%); Between 6 months and 1 year $13 \%$ of children are malnourished; Between one and two years the proportion of affected children becomes even higher (29.1\%). During this period, the child gradually changes his liquid and milk diet to a diversified semi-liquid, and solid diet [4]. Breastfeeding and complementary feeding are two interrelated steps. Indeed after 6 months, breast milk is not able to cover all the energy and nutrient needs of the child. It should be supplemented by foods with a good nutritional and microbiological value. In developing countries such as Côte d'Ivoire, weaning porridge is often poor in nutrients and contaminated with pathogenic microorganisms [5]. These porridges because of their poor quality have negative consequences on the nutritional status of children. In Côte d'Ivoire, the problem is more acute in rural areas where a quarter of children under 5 are affected by malnutrition. To help solve this problem of malnutrition we were interested in the weaning porridge given to children in Zokolilie, a rural area of Cote d'Ivoire. The aim of this study is to assess the nutritional and microbiological quality of ten weaning porridges in the rural area of Zokolilié in south-west of Ivory Coast. 


\section{Materials and Methods}

\subsection{Sampling and Selection of Weaning Porridge}

Ten weaning porridges frequently consumed by children in Zokolilie were selected for biochemical and microbiological analyzes (Table 1). Three samples were taken for each type of porridge ready to be consumed by children with their basic flours in clean, hermetically sealed vials and then stored in an ice box containing ice and conveyed as quickly as possible after no more than 3 hours in the laboratory for analyzes of a total of 60 samples.

Table 1. Porridges Code.

\begin{tabular}{ll}
\hline Porridge & Code \\
\hline Rice & Bri \\
Millet & BMi \\
Attiéké & BATT \\
Maize & BMa \\
Sorghum & BSOr \\
Biscuit & BBis \\
Sorghum and rice & BRiSor \\
Soy and rice & BRiSO \\
Maize and peanut & BMaAr \\
Maize, peanut and soy & BMaArSo \\
\hline
\end{tabular}

\subsection{Nutritional and Microbiological Analyzes of Weaning Slurries}

To determine the nutritional value of the slurries several analyzes were carried out. The dry matter, protein, lipid, carbohydrate and ash content were determined according to the method (AOAC, 1990). The content of polyphenols was determined according to the method described by Singleton et al. (1999). The phytates content was determined according to the method described by INRA (1990). The tannins were determined according to the method described by Bainbridge et al., (1996). The oxalate content was determined according to the method described by Day and underwood (1986). Finally, microbiological analyzes were carried out on the total flora, Staphylococcus aureus, Yeasts and molds, Escherichia. Coli Total coliforms, Salmonella and shiguella, Fecal coliforms.

\subsection{Statistical Analysis}

Data generated by this study were statistically processed using statistica software 7.1. The significance of values derived from the characterization of complementary foods was evaluated by the Duncan test at the 5\% threshold. Analysis of variance (ANOVA) made it possible to process data derived from biochemical, microbiological and hematological parameters. Whenever a significant difference $(\alpha<0.05)$ is revealed, the ANOVA test is supplemented by the Duncan post ANOVA test to identify the variable (s) with very significant differences from the control values.

\section{Results and Discussion}

\subsection{Biochemical Parameters of the Ten Porridges}

Only the millet porridge has a dry matter content lower than $15 \mathrm{~g} / 100 \mathrm{~g}$ (Table 2). Porridges with a dry matter content of less than $15 \mathrm{~g} / 100 \mathrm{~g}$ equivalent to an energy density of around 0.6 $\mathrm{Kcal} / \mathrm{g}$ remain insufficient to cover the energy needs of young children [6]. All the ten porridges are poor in dietary fiber, with levels ranging from $0.43 \pm 0.11 \mathrm{~g} / 100 \mathrm{~g} \mathrm{M}$. S for BRiSO to 9.88 $\pm 3.66 \mathrm{~g} / 100 \mathrm{~g} \mathrm{M}$. S for industrial biscuit. This could be explained by the fact that no mother adds fruit puree (banana, mango, or papaya) to infant porridge in the rural area of the study. But the fruits are rich in dietary fiber which can protect against constipation and hemorrhoids. In general, all the porridge are rich in carbohydrates. However, the carbohydrate content of the sorghum rice mixture $(96.83 \pm 0.62 \mathrm{~g} / 100 \mathrm{~g}$ of M. S) is very significant $(\mathrm{P}<5 \%)$. This could be explained by the synergy of two cereals rich in carbohydrates that are mixed to make a single porridge. The results show that all porridge are low in protein, except for the soybean rice slurry with a $16.87 \pm 0.18 \mathrm{~g} / 100 \mathrm{~g} \mathrm{M}$. $\mathrm{S}$ content above the recommended protein content $(15 \mathrm{~g} / 100 \mathrm{~g})$. The protein content of the soybean rice porridge is significantly different to the protein content of the other poridge $(p<5 \%)$. This is due to the high protein content of soybeans. The low protein content of other slurries is explained by the fact that no ingredients of animal origin were added during the preparation. On the other hand, all the porridges have a low content in fat. The lipid content of the simple slurries varies from $0.5 \pm 0.06 \mathrm{~g} / 100$ $\mathrm{g}$ of M. S for sorghum to $6.23 \pm 2.30 \mathrm{~g} / 100 \mathrm{~g}$ for BBis. The contents obtained outside that of BBis $(6.23 \pm 2.30 \mathrm{~g} / 100 \mathrm{~g}$ of M. $\mathrm{S})$ are not significantly different $(\mathrm{P}<5 \%)$. The biscuit slurry has a significant lipid content because it is made of dietary flours of sweetening material but mostly of fat providing lipid [7-8]. Moreover, the porridge composed of Maize-Peanuts and Maize-Arachid-Soja have significant contents respectively with $3.11 \pm 0.86$ and $3.28 \pm 0.03 \mathrm{~g} / 100 \mathrm{~g}$ of M. S. However, it should be noted that all the lipid contents of the porridge remain largely insufficient compared to the standard which is between 10-25 g/ $100 \mathrm{~g}$ of M. S. The energy values of the foods estimated from the awater coefficients) show that all single slurries have energy values close to the norm of codex alimentarius (400 kcal / $100 \mathrm{~g}$ of M. S) [8]. The single slurries of sorghum and millet with respectively $393.34 \pm 0.06$ and $390.675 \pm 2.98 \mathrm{Kcal} / 100 \mathrm{~g}$ contents have the highest energy values. It is the oil added to these porridge that probably confers their high energy value. All compound porridge have the energy values in accordance with the standard. The BMaArSO and BMaAr slurries with respectively $410.05 \pm 2.81$ and $406.22 \pm 0.06 \mathrm{Kcal} / 100 \mathrm{~g}$ are above the reference value which is $400 \mathrm{Kcal}$. The blending of flours on the one hand and the addition of the groundnut paste to the compound slurries are responsible for the high energy value of the compound slurries. However, the energy differences observed in all the porridge are not significant $(\mathrm{P}<5 \%)$. 
Table 2. Biochemical parameters of the porridge in $\mathrm{mg} / 100 \mathrm{~g}$ of $\mathrm{M} . \mathrm{S}$.

\begin{tabular}{|c|c|c|c|c|c|c|}
\hline \multirow{2}{*}{ Porridge } & \multicolumn{6}{|l|}{ Biochemical parameters } \\
\hline & Carbohydrate (g/100 g) & Protein (g/100 g) & fat $(g / 100 \mathrm{~g})$ & Fiber (g/100 g) & Dry matter (g/100 g) & Energy density (Kcal/100 g) \\
\hline Bri & $84,42 \pm 0,08^{c}$ & $5,41 \pm 0,23^{\mathrm{e}}$ & $1,2 \pm 0,43^{\mathrm{a}}$ & $3,62 \pm 0,35^{\mathrm{b}}$ & $17,9 \pm 0,51^{\mathrm{b}}$ & $370,12 \pm 3,26^{\mathrm{a}}$ \\
\hline BMi & $91,47 \pm 1,50^{d}$ & $3,78 \pm 0,83^{\mathrm{c}}$ & $1,075 \pm 0,04^{\mathrm{a}}$ & $2,965 \pm 0,71^{b}$ & $12,74 \pm 0,34^{\mathrm{a}}$ & $390,675 \pm 2,98^{\mathrm{a}}$ \\
\hline BATT & $89,49 \pm 2,91^{\mathrm{d}}$ & $5,18 \pm 1,14^{\mathrm{d}}$ & $0,56 \pm 0,20^{\mathrm{a}}$ & $2,33 \pm 2,04^{b}$ & $25,65 \pm 0,04^{\mathrm{c}}$ & $383,68 \pm 8,85^{\mathrm{a}}$ \\
\hline BMa & $87,68 \pm 0,05^{d}$ & $5,69 \pm 0,01^{\mathrm{e}}$ & $0,6 \pm 0,00^{\mathrm{a}}$ & $4,59 \pm 0,01^{\mathrm{c}}$ & $19,92 \pm 6,53^{c}$ & $378,84 \pm 0,23^{\mathrm{a}}$ \\
\hline Bsor & $95,56 \pm 0,21^{\mathrm{d}}$ & $1,65 \pm 0,07^{\mathrm{a}}$ & $0,5 \pm 0,06^{\mathrm{a}}$ & $1,65 \pm 0,07^{\mathrm{b}}$ & $21,43 \pm 0,60^{c}$ & $393,34 \pm 0,06^{\mathrm{a}}$ \\
\hline $\mathrm{BBis}$ & $74,05 \pm 2,59^{b}$ & $6,4 \pm 1,15^{\mathrm{e}}$ & $6,23 \pm 2,30^{\mathrm{d}}$ & $9,88 \pm 3,66^{\mathrm{e}}$ & $32,14 \pm 0,19^{\mathrm{e}}$ & $377,81 \pm 26,42^{\mathrm{a}}$ \\
\hline BRiSor & $96,83 \pm 0,62^{\mathrm{e}}$ & $1,76 \pm 0,34^{\mathrm{a}}$ & $0,44 \pm 0,08^{\mathrm{a}}$ & $0,51 \pm 0,10^{\mathrm{a}}$ & $18,86 \pm 3,62^{\mathrm{c}}$ & $400,68 \pm 0,34^{\mathrm{a}}$ \\
\hline BRiSO & $70,16 \pm 0,21^{\mathrm{a}}$ & $16,88 \pm 0,18^{\mathrm{f}}$ & $1,55 \pm 0,07^{\mathrm{b}}$ & $0,43 \pm 0,11^{\mathrm{a}}$ & $25,18 \pm 0,46^{\mathrm{c}}$ & $402,07 \pm 8,17^{\mathrm{a}}$ \\
\hline $\mathrm{BMaAr}$ & $92,6 \pm 0,06^{\mathrm{d}}$ & $1,58 \pm 0,01^{\mathrm{a}}$ & $3,28 \pm 0,03^{\mathrm{c}}$ & $0,47 \pm 0,01^{\mathrm{a}}$ & $31,5 \pm 0,21^{\mathrm{d}}$ & $406,22 \pm 0,06^{\mathrm{a}}$ \\
\hline BMaArSo & $92,04 \pm 2,20^{\mathrm{d}}$ & $3,48 \pm 0,96^{\mathrm{b}}$ & $3,11 \pm 0,86^{\mathrm{c}}$ & $0,62 \pm 0,17^{\mathrm{a}}$ & $20,41 \pm 5,66^{\mathrm{c}}$ & $410,05 \pm 2,81^{\mathrm{a}}$ \\
\hline
\end{tabular}

All averages followed by the same letter by exposing on the same column are not significantly different at the probability threshold $\mathrm{P}<0.05$

\subsection{Mineral Content of the Porridge}

The ash content in the two groups of slurries is low because the slurries themselves are poor in dry matter. The mineral contents are very variable from one slurry to another and even within a group of simple or compound porridge. The infantile porridge is rich sometimes in certain mineral elements and sometimes poor in other mineral elements. Of the (10) slurries studied, only four (4) had an iron content above the recommended value of $16 \mathrm{mg} / 100 \mathrm{~g}$ of M. S. These are the simple rice bouillies $(43.69 \pm 6.33)$; BATT $(21.89 \pm 9.06)$;
$(18.51 \pm 3.90)$ and the BMaAr compound flour slurry (42.36 \pm $3.48 \mathrm{mg} / 100 \mathrm{~g}$ of M. S.) (table 3 ). These porridges are rich in iron but are low in calcium. Calcium is brought in large part by the addition of milk to the ready-to-eat porridge. However, not all mothers have financial resources to offer infant formula to their offspring. Thus, on the (10) slurries consumed by the children, only two (02) slurries have a calcium / phosphorus ratio greater than one (1). These are in ascending order the Attiéké slurry with a ratio of 1.2 and the slurry of Rice with a ratio of 3.36 (table 4).

Table 3. Mineral content of the ten Porridge.

\begin{tabular}{|c|c|c|c|c|c|c|c|}
\hline \multirow{2}{*}{ Porridge } & \multicolumn{7}{|l|}{ PARAMETER } \\
\hline & $\mathrm{Na}(\mathrm{mg} / 100 \mathrm{~g})$ & $\mathrm{Mg}(\mathrm{mg} / 100 \mathrm{~g})$ & $P(\mathrm{mg} / 100 \mathrm{~g})$ & $\mathrm{Ca}$ (mg/100 g) & $\mathrm{Fe}(\mathrm{mg} / 100 \mathrm{~g})$ & $\mathrm{Zn}(\mathrm{mg} / 100 \mathrm{~g})$ & $\operatorname{Ash}(g / 100 \mathrm{~g})$ \\
\hline Bri & $156,04 \pm 58,08^{c}$ & $201,70 \pm 36,46^{\mathrm{e}}$ & $116,10 \pm 30,26^{c}$ & $391,09 \pm 60,13^{\mathrm{c}}$ & $43,69 \pm 6,33^{f}$ & $18,37 \pm 7,94^{b}$ & $5,35 \pm 0,07^{\mathrm{h}}$ \\
\hline BMi & $16,64 \pm 0,71^{\mathrm{a}}$ & $32,49 \pm 0,32^{\mathrm{a}}$ & $79,80 \pm 2,79^{a}$ & $20,00 \pm 0,65^{\mathrm{a}}$ & $4,05 \pm 1,47^{\mathrm{a}}$ & $0,66 \pm 0,39^{\mathrm{a}}$ & $0,71 \pm 0,01^{\mathrm{c}}$ \\
\hline BATT & $184,32 \pm 0,71^{\mathrm{c}}$ & $119,23 \pm 15,65^{\mathrm{d}}$ & $292,37 \pm 9,62^{d}$ & $350,19 \pm 45,17^{\mathrm{c}}$ & $21,89 \pm 19,06^{\mathrm{e}}$ & $0,00 \pm 0^{\mathrm{a}}$ & $2,45 \pm 0,07^{\mathrm{f}}$ \\
\hline BMa & $100,20 \pm 25,75^{\mathrm{b}}$ & $72,69 \pm 3,19^{c}$ & $180,91 \pm 10,19^{\mathrm{e}}$ & $47,85 \pm 4,70^{\mathrm{a}}$ & $18,51 \pm 3,90^{\mathrm{d}}$ & $0,00 \pm 0^{a}$ & $1,45 \pm 0,07^{\mathrm{d}}$ \\
\hline Bsor & $38,08 \pm 6,03^{a}$ & $29,46 \pm 1,75^{\mathrm{a}}$ & $81,32 \pm 7,28^{\mathrm{a}}$ & $16,79 \pm 0,89^{\mathrm{a}}$ & $0,73 \pm 0,16^{\mathrm{c}}$ & $1,54 \pm 1,46^{\mathrm{a}}$ & $0,64 \pm 0,01^{\mathrm{b}}$ \\
\hline $\mathrm{BBis}$ & $835,94 \pm 27,14^{\mathrm{d}}$ & $50,49 \pm 5,02^{b}$ & $383,76 \pm 25,68^{f}$ & $80,96 \pm 15,39^{b}$ & $11,73 \pm 3,97^{\mathrm{a}}$ & $17,71 \pm 3,09^{\mathrm{a}}$ & $3,45 \pm 0,07^{\mathrm{g}}$ \\
\hline BRiSor & $32,26 \pm 5,74^{\mathrm{a}}$ & $22,38 \pm 1,16^{\mathrm{a}}$ & $59,04 \pm 1,67^{b}$ & $19,07 \pm 0,86^{\mathrm{a}}$ & $12,73 \pm 2,82^{b}$ & $0,53 \pm 0,23^{\mathrm{a}}$ & $0,47 \pm 0,09^{\mathrm{a}}$ \\
\hline BRiSO & $10,21 \pm 2,98^{\mathrm{a}}$ & $42,12 \pm 4,62^{\mathrm{a}}$ & $94,27 \pm 1,83^{\mathrm{a}}$ & $25,48 \pm 3,71^{\mathrm{a}}$ & $5,31 \pm 0,50^{\mathrm{a}}$ & $0,65 \pm 0,23^{\mathrm{a}}$ & $0,65 \pm 0,07^{\mathrm{b}}$ \\
\hline BMaAr & $91,45 \pm 25,70^{b}$ & $116,83 \pm 20,84^{d}$ & $277,68 \pm 4,32^{\mathrm{d}}$ & $53,18 \pm 5,53^{\mathrm{a}}$ & $42,36 \pm 3,48^{\mathrm{f}}$ & $0,00 \pm 0^{\mathrm{a}}$ & $2,08 \pm 0,01^{\mathrm{e}}$ \\
\hline BMaArSo & $26,55 \pm 6,52^{\mathrm{a}}$ & $41,07 \pm 6,40^{\mathrm{a}}$ & $89,79 \pm 17,25^{\mathrm{a}}$ & $14,60 \pm 0,89^{\mathrm{a}}$ & $9,34 \pm 0,86^{\mathrm{a}}$ & $0,08 \pm 0,07^{\mathrm{a}}$ & $0,76 \pm 0,21^{\mathrm{c}}$ \\
\hline
\end{tabular}

All averages followed by the same letter by exposing on the same column are not significantly different at the probability threshold $\mathrm{P}<0.05$

Table 4. Ratio Calcium / phosphorus.

\begin{tabular}{ll}
\hline \multirow{2}{*}{ Porridge } & Ratio \\
\cline { 2 - 2 } & Calcium / phosphorus \\
\hline Bri & 3,36 \\
BMi & 0,25 \\
BATT & 1,20 \\
BMa & 0,26 \\
Bsor & 0,20 \\
BBis & 0,21 \\
BRiSor & 0,32 \\
BRiSO & 0,27 \\
BMaAr & 0,19 \\
BMaArSo & 0,16 \\
\hline
\end{tabular}

\subsection{Anti-nutrient Contents of the Ten Porridges}

The presence of antinutritional factors in slurries affects the bioavailability of mineral. The Phytates / calcium ratios of all the slurries consumed are higher than the critical reference threshold 0.2 [9-10]. These results show that the local slurries are loaded with phytates which inhibit cations contained in the slurries, in particular calcium, zinc, magnesium, and iron. All single slurries have an oxalate / calcium quotient below the critical threshold 2.5. However due to the ratio of Phytates / high calcium in the same single porridge, only the local rice and Attiéké porridge have available calcium. The Phytates / iron ratios in the various slurries are very high. The values obtained exceeded the critical reference threshold of 0.4 for the bioavailability of iron in weaning porridge [8-11]. Iron, although present in the porridges, is not available. This unavailability of iron in complementary foods is explained by the fact that the high concentration of Phytates chelates iron making it unavailable for consumption. This fact results in iron deficiency noted in children from which ferric anemia. These results are consistent with the work of some authors who reported that phytates and oxalic acid found in many plants (fruits, vegetables and cereals) decreased the absorption of calcium, zinc, Magnesium and iron by complexing them [12]. Calcium is necessary for the formation and maintenance of the bones but also for the regulation of the heartbeat. 
Table 5. Antinutrient contents of different weaning porridge in $\mathrm{mg} / 100 \mathrm{~g}$

\begin{tabular}{|c|c|c|c|c|c|}
\hline \multirow{2}{*}{ Porridge } & \multicolumn{5}{|l|}{ Parameter } \\
\hline & Polyphenols (mg/100 g) & Tannins (mg/100 g) & Phytates (mg/100 g) & Oxalates (mg/100 g) & Flavonoids $(\mathrm{mg} / 100 \mathrm{~g})$ \\
\hline Bri & $45,635 \pm 0,000^{\mathrm{c}}$ & $50,161 \pm 0,000^{\mathrm{b}}$ & $101,657 \pm 0,070^{\mathrm{g}}$ & $22,215 \pm 0,000^{\mathrm{a}}$ & $2,428 \pm 0,221^{\mathrm{d}}$ \\
\hline $\mathrm{BMi}$ & $55,556 \pm 0,000^{\mathrm{e}}$ & $33,870 \pm 0,371^{\mathrm{a}}$ & $97,737 \pm 0,070^{\mathrm{f}}$ & $33,154 \pm 0,000^{b}$ & $0,368 \pm 0,255^{a}$ \\
\hline BATT & $261,905 \pm 0,992^{i}$ & $587,353 \pm 0,371^{\mathrm{j}}$ & $101,818 \pm 0,000^{\mathrm{h}}$ & $99,010 \pm 0,000^{d}$ & $2,502 \pm 0,337^{\mathrm{e}}$ \\
\hline BMa & $34,061 \pm 0,573^{b}$ & $88,317 \pm 0,371^{\mathrm{c}}$ & $87,152 \pm 0,000^{b}$ & $22,214 \pm 0,003^{a}$ & $9,934 \pm 0,000^{\mathrm{g}}$ \\
\hline Bsor & $47,288 \pm 0,573^{d}$ & $187,781 \pm 0,000^{\mathrm{f}}$ & $87,313 \pm 0,070^{c}$ & $33,154 \pm 0,001^{\mathrm{b}}$ & $2,723 \pm 0,128^{\mathrm{e}}$ \\
\hline $\mathrm{BBis}$ & $85,317 \pm 0,00^{\mathrm{f}}$ & $165,487 \pm 0,371^{\mathrm{e}}$ & $85,414 \pm 0,070^{\text {a }}$ & $44,310 \pm 0,000^{c}$ & $1,178 \pm 0,128^{b}$ \\
\hline BRiSor & $31,746 \pm 0,000^{\mathrm{a}}$ & $91,318 \pm 0,000^{d}$ & $92,040 \pm 0,070^{\mathrm{e}}$ & $132,117 \pm 0,000^{\mathrm{e}}$ & $3,753 \pm 0,221^{\mathrm{f}}$ \\
\hline BRiSO & $125 \pm 0,000^{\mathrm{g}}$ & $281,458 \pm 0,371^{\mathrm{g}}$ & $88,606 \pm 0,000^{d}$ & $22,215 \pm 0,001^{\mathrm{a}}$ & $0,883 \pm 0,382^{b}$ \\
\hline BMaAr & $210,648 \pm 0,573^{h}$ & $408,360 \pm 0,000^{h}$ & $105,131 \pm 0,070^{j}$ & $44,311 \pm 0,001^{\mathrm{c}}$ & $3,458 \pm 0,128^{\mathrm{f}}$ \\
\hline BMaArSo & $303,240 \pm 0,573^{j}$ & $427,653 \pm 0,000^{\mathrm{i}}$ & $103,717 \pm 0,070^{i}$ & $44,309 \pm 0,000^{c}$ & $2,060 \pm 0,337^{\mathrm{c}}$ \\
\hline
\end{tabular}

All averages followed by the same letter by exposing on the same column are not significantly different at the probability threshold $\mathrm{P}<0.05$

Table 6. Ratio anti-nutrient / mineral.

\begin{tabular}{llll}
\hline \multirow{2}{*}{ Porridge } & Ratio & & \\
\cline { 2 - 4 } & [Phytates]/ [calcium] & [Phytates]/ [Iron] & [Oxalates]/[calcium] \\
\hline Bri & 0,26 & 2,31 & 0,05 \\
BMi & 4,88 & 24,19 & 1,65 \\
BATT & 0,29 & 4,67 & 0,28 \\
BMa & 1,82 & 4,69 & 0,47 \\
Bsor & 5,18 & 5,11 & 1,96 \\
BBis & 1,05 & 7,28 & 0,55 \\
BRiSor & 4,82 & 7,22 & 6,93 \\
BRiSO & 3,47 & 16,62 & 0,87 \\
BMaAr & 1,97 & 2,47 & 0,83 \\
BMaArSo & 7,11 & 11,08 & 3,04 \\
\hline
\end{tabular}

\subsection{Microbiological Quality of Weaning Slurries}

Mesophilic aerobic germs or total flora are indicators of "hygiene test" for the food [12-13]. Their presence the ten porridges indicates poor food preservation and ineffective heat treatment. Indeed, $8.5 \%$ of mothers cook the porridge for less than 10 minutes [14]. This time is insufficient for the destruction of the total flora present in the slurries. Moreover, the presence of considerable mesophilic germs in food could indicate contamination of raw materials, lack of hygiene at the preparation or storage stage [13-15]. The cooking water used by mothers may also be a source of contamination. In fact, $96.5 \%$ of mothers use covered wells, compared to $2 \%$ of mothers using tap water, $1 \%$ of mothers use uncovered wells and $0.5 \%$ of spring water mothers. The personal hygiene of mothers and kitchen utensils is not a source of contamination because $77.5 \%$ of mothers wash their hands with soap before preparing complementary food and $80 \%$ of mothers do so To feed the child. Moreover, the utensils used to prepare the child's food are at $98.5 \%$ different from the utensils of the parents and are $84 \%$ washed with soap. This makes it possible to avoid recontamination of the slurries after cooking and a significant reduction of the total flora in the ready-to-eat porridge. The massive presence of yeasts and molds in local flours is an indication of a very inadequate or insufficient heat treatment process or of post-treatment contamination [14-16-17]. Indeed local flours produced from cereals are dried in the open air often on the ground on plastic. Dust from the air, domestic animals and other creatures are in constant contact with these local flours to deposit germs. Certain germs of mold are responsible not only for the degradation of food but also for the secretion of toxins which are fatal substances for the consumer. On the other hand, after cooking, no slurry contains yeasts and molds. This is because at least $78.7 \%$ of mothers cook porridge for children between 15 and 60 minutes. On the other hand $98.58 \%$ of the mothers cook the porridge until the appearance of foam boiling sign. However, heating at $90^{\circ} \mathrm{C}$ for 60 seconds would be sufficient to sterilize the medium [17-18-19-20]. Then $75.5 \%$ of the mothers give the porridge to their children the minutes after cooling under good hygienic conditions, canceling all the risks of recontamination.

Table 7. Microbial loads of porridge $(\times 104 u f c)$.

\begin{tabular}{|c|c|c|c|c|c|c|c|}
\hline \multirow[b]{2}{*}{ Porridge } & \multicolumn{7}{|c|}{ Parameter $\left(\times 10^{4}\right.$ UFC/g) } \\
\hline & $\begin{array}{l}\text { Staphyloccocus } \\
\text { aureus }\end{array}$ & $\begin{array}{l}\text { Total microbial } \\
\text { flora }\end{array}$ & $\begin{array}{l}\text { Yeasts and } \\
\text { molds. }\end{array}$ & $\begin{array}{l}\text { Escherichia. } \\
\text { Coli }\end{array}$ & Total Coliforms & $\begin{array}{l}\text { Salmonella and } \\
\text { shiguella }\end{array}$ & Fecal Coliforms \\
\hline B.Ri & $0 \pm 0,00^{\mathrm{a}}$ & $0 \pm 0,00^{\mathrm{a}}$ & $0 \pm 0,00^{\mathrm{a}}$ & $0 \pm 0,00^{\mathrm{a}}$ & $0 \pm 0,00^{\mathrm{a}}$ & $0 \pm 0,00^{\mathrm{a}}$ & $0 \pm 0,00^{\mathrm{a}}$ \\
\hline B.Mi & $0 \pm 0,00^{\mathrm{a}}$ & $0,03 \pm 0,04^{\mathrm{a}}$ & $0 \pm 0,00^{\mathrm{a}}$ & $0 \pm 0,00^{\mathrm{a}}$ & $0 \pm 0,00^{\mathrm{a}}$ & $0 \pm 0,00^{\mathrm{a}}$ & $0 \pm 0,00^{\mathrm{a}}$ \\
\hline B.ATT & $0 \pm 0,00^{\mathrm{a}}$ & $0 \pm 0,00^{\mathrm{a}}$ & $0 \pm 0,00^{\mathrm{a}}$ & $0 \pm 0,00^{\mathrm{a}}$ & $0 \pm 0,00^{\mathrm{a}}$ & $0 \pm 0,00^{\mathrm{a}}$ & $0 \pm 0,00^{\mathrm{a}}$ \\
\hline B.Ma & $0 \pm 0,00^{\mathrm{a}}$ & $0 \pm 0,00^{\mathrm{a}}$ & $0 \pm 0,00^{\mathrm{a}}$ & $0 \pm 0,00^{\mathrm{a}}$ & $0 \pm 0,00^{\mathrm{a}}$ & $0 \pm 0,00^{\mathrm{a}}$ & $0 \pm 0,00^{\mathrm{a}}$ \\
\hline B.Bis & $0 \pm 0,00^{\mathrm{a}}$ & $0,004 \pm 0,0001^{\mathrm{a}}$ & $0 \pm 0,00^{\mathrm{a}}$ & $0 \pm 0,00^{\mathrm{a}}$ & $0 \pm 0,00^{\mathrm{a}}$ & $0 \pm 0,00^{\mathrm{a}}$ & $0 \pm 0,00^{\mathrm{a}}$ \\
\hline B.MaAr & $0 \pm 0,00^{\mathrm{a}}$ & $0 \pm 0,00^{\mathrm{a}}$ & $0 \pm 0,00^{\mathrm{a}}$ & $0 \pm 0,00^{\mathrm{a}}$ & $0 \pm 0,00^{\mathrm{a}}$ & $0 \pm 0,00^{\mathrm{a}}$ & $0 \pm 0,00^{\mathrm{a}}$ \\
\hline BMaArSO & $0 \pm 0,00^{\mathrm{a}}$ & $0 \pm 0,00^{\mathrm{a}}$ & $0 \pm 0,00^{\mathrm{a}}$ & $0 \pm 0,00^{\mathrm{a}}$ & $0 \pm 0,00^{\mathrm{a}}$ & $0 \pm 0,00^{\mathrm{a}}$ & $0 \pm 0,00^{\mathrm{a}}$ \\
\hline BRiSo & $0 \pm 0,00^{\mathrm{a}}$ & $0 \pm 0,00^{\mathrm{a}}$ & $0 \pm 0,00^{\mathrm{a}}$ & $0 \pm 0,00^{\mathrm{a}}$ & $0 \pm 0,00^{\mathrm{a}}$ & $0 \pm 0,00^{\mathrm{a}}$ & $0 \pm 0,00^{\mathrm{a}}$ \\
\hline BRiSor & $0 \pm 0,00^{\mathrm{a}}$ & $0,5 \pm 0,04^{b}$ & $0 \pm 0,00^{\mathrm{a}}$ & $0 \pm 0,00^{\mathrm{a}}$ & $0 \pm 0,00^{\mathrm{a}}$ & $0 \pm 0,00^{\mathrm{a}}$ & $0 \pm 0,00^{\mathrm{a}}$ \\
\hline
\end{tabular}

All averages followed by the same letter by exposing on the same column are not significantly different at the probability threshold $\mathrm{P}<0.05$ 


\section{Conclusion}

The ten Zokolilié porridges are generally poor in dry matter, fiber, protein, fat, but high in carbohydrates. The mineral contents are very variable from one porridge to another. The high concentration of antinutritional factors in the ten porridges could inhibit the bioavailability of mineral salts, especially iron, and cause iron anemia. The presence of the total flora in three porridges indicates poor food preservation and ineffective heat treatment.

\section{References}

[1] Black RE, Victora CG, Walker SP, Bhutta ZA, Christian P, de Onis $M$, et al. Maternal and child undernutrition and overweight in low-income and middle-income countries. Lancet. 2013; 382 (9890): 427.

[2] World Health Organization. World health statistics. Geneva: WHO report; 2014.

[3] Mahgoub EO, Nnyepi M, Bandeke T. Factors affecting prevalence of malnutrition among children under three years of age in Botswana. Afr J Food Agric Nutr Dev. 2006; 6: 1.

[4] KIGER J. L., KIGER J. G, 1967. Techniques modernes de biscuiterie, pâtisserie, boulangerie industrielle et artisanale et les produits de régime. Edition, DUNO. Paris. 676 pages.

[5] HASSAN H. M. M., AFIFY A. S., BASYIONY A. E., AHMED GHADA T., 2010. Nutritional and Functional Properties of Defatted Wheat Protein Isolates. Australian Journal of Basic and Applied Sciences, 4 (2): 348-358.

[6] Savage A., HUSSEIN K., 1964, Barely Flour and Durum Flour Blends in Macaroni Product. Australian Journal of Basic and Applied Sciences, 4 (12): 6169-6178.

[7] Ana R. De Boland, George B. Garner, Boyd L. O'Dell, Identification and properties of phytate in cereal grains and oilseed products, J. Agric. Food Chem., 1975, 23 (6), pp 1186 1189.

[8] Boyd L. O'Dell, Ana R. De Boland, Samuel R. Koirtyohann, Distribution of phytate and nutritionally important elements among the morphological components of cereal grains, J. Agric. Food Chem., 1972, 20 (3), pp 718-723.
[9] Adams, M. R. (1998). Fermented weaning foods. In J. B. Wood (Ed.), Microbiology of fermented foods (pp. 790-811). London: Blackie Academic.

[10] Adeniji, A. O., \& Potter, N. N. (1978). Properties of ogi powders made from normal, fortified and opaque- 2 corn. Journal of Food Science, 43, 1571-1574.

[11] Akinrele, I. A., \& Bassir, O. (1967). The nutritive value of ogi, a Nigerian infant food. Journal of Tropical Medicine and Hygiene, 70, 279-280.

[12] Gibson RS, Ferguson EL, Lehrfeld J. Complementary foods for infant feeding in developing countries: their nutrient adequacy and improvement. Eur J Clin Nutr 1997; 52: 764-70.

[13] Ana R. De Boland, George B. Garner, Boyd L. O'Dell, Identification and properties of phytate in cereal grains and oilseed products J. Agric. Food Chem., 1975, 23 (6), pp 1186 1189.

[14] Boyd L. O'Dell, Ana R. De Boland, Samuel R. Koirtyohann, Distribution of phytate and nutritionally important elements among the morphological components of cereal grains J. Agric. Food Chem., 1972, 20 (3), pp 718-723.

[15] Adams, M. R. (1998). Fermented weaning foods. In J. B. Wood (Ed.), Microbiology of fermented foods (pp. 790-811). London: Blackie Academic.

[16] Adeniji, A. O., \& Potter, N. N. (1978). Properties of ogi powders made from normal, fortified and opaque-2 corn. Journal of Food Science, 43, 1571-1574.

[17] Akinrele, I. A., \& Bassir, O. (1967). The nutritive value of ogi, a Nigerian infant food. Journal of Tropical Medicine and Hygiene, 70, 279-280.

[18] Gibson RS, Ferguson EL, Lehrfeld J. Complementary foods for infant feeding in developing countries: their nutrient adequacy and improvement. Eur J Clin Nutr 1997; 52: 764-70.

[19] Jelliffe DB, Jelliffe EFP. The volume and composition of human milk in poorly nourished communities: a review. Am J Clin Nutr 1978; 31: 492-515.

[20] Rahman H, Jalil MA, Rahman A, et al. Nutritional status of children in rural Bangladesh. Dhaka: Institute of Public Health Nutrition and Helen Keller International, Mohakhali Health Complex, 1984. 